\title{
1.2 Інституційне забезпечення раціонального використання і охорони земельних ресурсів
}

Земля відіграє найважливішу загально-біосферну роль i $\epsilon$ фундаментальною основою функціонування атмосфери, гідросфери та інших сфер розвитку рослинного і тваринного світів, а також людського суспільства. В аграрному секторі земля - головний засіб виробництва, найважливіша складова ресурсної бази землеробства. Продуктивні сільськогосподарські землі цілком справедливо вважають унікальним природним і виробничим ресурсом, який, на відміну від інших природних ресурсів, за умов раціонального та екологічно виваженого використання здатний не зменшуватися i не втрачати своєї родючості. Оскільки лише відносно невелика частина земної кулі вкрита родючим шаром грунту, що може використовуватися для ведення сільського господарства - основного продуцента продовольства, - то проблема всебічної охорони земель, збереження та відтворення родючості грунтів, раціоналізації та екологізації аграрного землекористування - це проблема продовольча, економічна, екологічна i загалом проблема національної безпеки будь-якої країни.

На сучасному етапі людської цивілізації охорона і раціональне використання земель - основне соціально-економічне й екологічне завдання суспільства, найважливіша передумова національної безпеки будь-якої держави. Особливо актуальною ця проблема є для України, оскільки її земельні ресурси зазнають значних антропогенних навантажень і деградують стрімко.

Україна має один із найвищих у світі рівнів сільськогосподарської освоєності й розораності території. У власності та користуванні аграрних підприємств і господарств понад 47 млн га земель, що становить близько 78 \% загальної території України. Сьогодні невиправдано розпорошуються дефіцитні матеріально-технічні й особливо енергетичні ресурси, а природі та суспільству завдають величезної шкоди - деградують і еродують чорноземи, забруднюються водойми, знижуються якість і екологічна чистота продовольства. Проблема 
організації раціонального використання й охорони земельних ресурсів залишається найбільш актуальною. Ринкові відносини суттєво впливають на раціональне природокористування.

А. Журавський та В. Акуленко стверджують, що питання охорони навколишнього середовища і раціонального використання природних ресурсів необхідно розглядати в єдності з розвитком продуктивних сил, так само як $\mathrm{i}$ розвиток останніх повинен бути пов’язаним із процесами відтворення природних умов і факторів [29, с. 64].

На думку А. Никонова, до причин виникнення економічної кризи необхідно віднести і фактичну відсутність природоохоронного економічного механізму, що проявлялось у відносно низьких, порівняно зі світовими, цінами, цін на сировину і матеріали, безоплатному користуванні природними ресурсами, зокрема землею, малих обсягах капітальних вкладень на екологічні цілі, пом’якшених санкцій за порушення природного середовища [30, с. 225].

Нераціональне природокористування пов’язане 3 відсутністю власника природних ресурсів, що спричиняло у природокористуванні інстинкти бездонності стосовно запасів природних благ та обсягів їх залучення у господарський обіг. Стосовно цього академік О. Богомолов зазначав: щоб нагодувати країну, потрібно дати селянину землю, надавши право вільно господарювати і реалізувати свою продукцію [31, с. 81].

На передачу права власності місцевим радам вказував Г. Попов, стверджуючи, що поява справжніх господарів на землі дозволить уникнути в значних обсягах сучасних згубних форм зрошення й осушення, неконтрольованого застосування пестицидів, нітратів і т. д. [32, с. 184]. Тим більше, для інституціоналізації нових для тогочасного суспільства форм власності на природні ресурси вже були не тільки інституціальні передумови, а й психологічні.

Деструктив у сферу природокористування внесли прорахунки, допущені під час проектування господарських заходів, що призвело до розбалансованості еколого-економічних систем (це стосується передусім меліорованих земель). 
Завдяки земельній реформі можливий рівноправний розвиток державної й приватної форм власності на землю з можливістю інституційного забезпечення організації раціонального використання землі. Домінуючий розвиток мають ті форми власності на землю, які зможуть забезпечити найвищу продуктивність праці та ефективність використання землі за умови збереження ії родючості.

Питання економічно ефективного та раціонального використання земель, охорони земельного фонду, відтворення родючості грунтів стали проблемою національної безпеки держави і потребують постійної уваги органів державної влади та органів місцевого самоврядування.

Із упровадженням в Україні приватної власності на землю докорінно змінилися земельні відносини. Приватизація земель в наслідок недостатнього інституційного забезпечення, відсутності державного контролю, призводить до масових порушень земельного законодавства на всіх рівнях щодо раціонального використання й охорони земель. Розподіл земель на земельні частки (паї) зумовив порушення організації території сільськогосподарських підприємств. Охорона земельного фонду в процесі земельної реформи перетворилась на значну загальнодержавну проблему, яка здебільшого формує питання екологічної безпеки держави. Земельні перетворення, формування сільськогосподарських підприємств, надання і вилучення земель відбувалися в стислий термін, що призвело до низки проблем та необхідності вдосконалення державної політики в галузі сільського господарства й економіки в загалом. Реалістичний стан земельної реформи з ії помилками відтворили М.А. Хвесик і В.А. Голян [33].

Серед помилок, які спричинили проблему в землекористуванні виокремлено:

- не було вироблено науково обгрунтованої стратегії й тактики, земельна реформа не мала програми чітко визначеної мети;

- не була підготовлена матеріальна і графічна бази, відсутні інвентаризаційні матеріали; 
- не визначено призначення малопродуктивних і деградованих земель щодо їх форми власності;

- зміна форми власності на землю, земельні відносини, організацію виробництва та управління зменшили ефективність використання земельних ресурсів;

- відсутність ведення в новостворених господарствах моніторингу грунтів, подальша деградація їх призводять до погіршення якості грунтів;

- відсутність розробки проектів землеустрою сільськогосподарських підприємств призвела до втрати функцій планування, як основи у системі управління використанням і охороною земельних ресурсів;

- відсутність конкретних заходів щодо виведення ріллі 3 обробітку (консервація деградованих земель, введення агролісомеліоративних заходів, гідротехнічної меліорації, розширення природно-заповідних територій).

Отже, початкові умови функціонування сільськогосподарського підприємства відіграють другорядну роль для організації високоефективного сільськогосподарського виробництва, а першочерговим $\epsilon$ інституційне забезпечення організації раціонального використання земель, які перебувають в інтенсивному сільськогосподарському обробітку.

Раціональне використання земель передбачає певні принципи:

- розподіл земель за формами власності;

- цільове використання земельних ресурсів;

- пріоритетне виділення сільському господарству родючих земель;

- врахування зональних особливостей використання землі;

- планомірність організації використання земельних ресурсів;

- збільшення родючості грунтів;

- охорона земель;

- впорядкування території.

Грунтозахисна та землезахисна спрямованість усіх заходів, які застосуються у використанні земельних ресурсів та розвитку земельних відносин, приведе до впровадження в усіх галузях та сферах економіки 
інституційного забезпечення раціонального, екологічно-врівноваженого й екологобезпечного землекористування та володіння землею.

Основним питанням на сучасному етапі формування земельних відносин $€$ питання про право власності на землю. У цьому аспекті особливого значення набувають нові землевласники та землекористувачі та впровадження в усіх галузях та сферах економіки інституційного забезпечення раціонального, екологічноврівноваженого й екологобезпечного землекористування та володіння землею.

У розвитку сільського господарства, особливого значення набуває проблема оренди землі як у теоретичному, так і в прикладному аспектах, а також передачі землі в оренду іноземним громадянам, підприємцям. Оренду земель слід розглядати як форму організації виробництва яка сформована на основі приватної форми власності в системі функціонування ринку земель сільськогосподарського призначення. Сьогодні оренда землі є основною формою масштабного виробництва сільськогосподарської продукції.

Оренда внутрішньо дуже суперечлива, що зумовлено протиріччям прав власника землі та іï орендаря, а також межею правового впливу держави на орендні відносини. Це передусім стосується терміну оренди, який власник намагається скоротити, а орендар - збільшити, щоб мати змогу окупити витрати на збереження родючості землі за інтенсифікації виробництва. 3 цієї позиції, особливе значення надається довгостроковій оренді правом успадкування та викупу, тобто наступному переходу землі у приватну власність.

Внесення земельних ресурсів у реальний економічний оборот на основі функціонування ринку землі є важливою передумовою створення необхідних фондів для інституційного збереження, охорони та відтворення родючості сільськогосподарських угідь, упровадження екологобезпечних та природонеруйнівних землеволодінь і землекористувань у державі. Крім того, значно поліпшиться розподіл земель між галузями і сферами народного господарства, пришвидшаться процеси формування екологічно стійких і природоощадних агроландшафтів у всіх природно-кліматичних зонах країни. 
У сучасних екологічних і економічних умовах об'єктивно назріла потреба вартісної оцінки земельних ресурсів залежно від рівня їх родючості, агроекологічного стану, стану хімічного забруднення пестицидами та елементами важких металів.

Виведення малопродуктивних $\mathrm{i}$ техногенно-забруднених земель iз сільськогосподарського обороту, переведення розораних земель у сінокоси та культурні пасовища, а у крайніх випадках - тимчасова консервація земель, сприятимуть відновленню ними природного екологічного стану. При цьому товаровиробники втрачатимуть прибуток від спаду інтенсифікації використання земель. Стимулююча роль держави виявиться у частковій компенсації таких втрат прибутку.

Важливим і не вирішеним залишається грунтозахисна спрямованість усіх заходів, що стосується використання земельних ресурсів і розвитку земельних відносин, має зумовити впровадження в усіх галузях та сферах економіки інституційного забезпечення раціонального використання земель 3 дотриманням еколого безпечного землекористування через:

- забезпечення раціонального, невиснаженого, грунтозахисного та екологобезпечного землекористування в інтересах ефективного і сталого соціально - економічного розвитку країни;

- комплексний, науково обгрунтований підхід до процесів використання, збереження та відтворення родючості сільськогосподарських угідь, здійснення збалансованих землемеліоративних і землеохоронних заходів;

- формування в усіх землеробських регіонах високопродуктивних, ерозійно стійких та екологобезпечних агроландшафтів;

- удосконалення структури сільськогосподарських угідь і посівів вирощуваних культур у напрямі істотного зменшення негативних антропотехногенних навантажень на навколишнє природне середовище та зростання його відтворювального, відновлювального і асиміляційного процесу.

Організація раціонального використання земель $є$ функцією землевпорядкування, де заходи спрямовуються на виконання положень 
земельного законодавства та рішень місцевих рад. Змінилася організація раціонального використання земель, де повинні враховуватися розвиток всіх форм власності на землю, збереження та відтворення родючості грунтів. Використання землі має обов'язково узгоджуватися 3 продуктивністю конкретної земельної ділянки, відповідно до чого і визначається пріоритетність та цільовий характер передачі земель у власність чи надання у користування.

Отже, інституційне забезпечення організації раціонального використання земель в умовах розвитку різних форм власності залишається відкритою проблемою у використанні земель із необхідністю дотримання приведених заходів охорони земель із збереженням їх родючості.

Важливими показниками щодо використання орних земель мають бути:

- нормативна грошова оцінка, яку доцільно визначити не за фактичними показниками, а за нормативами затрат на вирощення природного врожаю на різних за якістю землях і диференціального рентного доходу.

- для визначення диференціального рентного доходу, як стартовий відлік, Для більш організованого використання земель, особливо сільськогосподарського призначення, А. М. Третяком було запроваджено еколого-економічну оцінку придатності земель, яка дозволить зробити сільськогосподарські землекористування більш інвестиційно привабливими. Ця методика поділяла сільськогосподарські землі на 5 класів.

Найбільш інвестиційно привабливими є орні землі першого класу. Це кращі за грунтами й технологічними властивостями земельні ділянки ріллі, 3 рівним або слабохвилястим рельєфом, які не підлягають ерозії. Ступінь окультуреності грунтів висока або вища за середню, окупність затрат становить понад 1,35 за вирощування всіх сільськогосподарських культур.

Землі другого класу мають певні обмеження через ерозійну небезпеку, слабке перезволоження, яке регулюється агротехнікою, придатні для вирощування всіх сільськогосподарських культур, але потребують протиерозійних заходів. 
Землі третього класу мають певні обмеження, які призводять до скорочення набору можливих культур (низька водопроникність, кам’янистість, слаба ерозія, окупність затрат становить менше ніж 1,35).

Землі четвертого і п'ятого класів мають значні i, відповідно, сильні обмеження (великі схили, підданість ерозії). Це грунти з низькою родючістю, за винятком чорноземів і темно-сірих грунтів. За відповідної агротехніки можуть використовуватися як кормові угіддя або постійне залуження.

В таблиці 1 приведемо приклад еколого-економічної класифікації орних земель Тернопільської області.

Згідно із поданою класифікацією, землі одного й того самого класу мають оцінку відповідно до обмежень їх використання в сільському господарстві і показують відповідність комплексу грунтових і технологічних властивостей конкретної ділянки для вирощування певної сільськогосподарської культури, виходячи з економічної ефективності виробництва іï прибутковості.

Еколого-економічна класифікація орних земель формує інвестиційну привабливість сільськогосподарських підприємств.

Для зростання кредитоспроможності (сільськогосподарських землекористувачів) слід упровадити:

- економічну класифікацію придатності земель, оцінку стану сільськогосподарських підприємств та бізнес-планів розвитку;

- ринковий обіг земельних ділянок із можливістю їх застави під інвестиційні кредити за жорсткого контролю держави.

Отже, інвестиційно привабливі типи землекористувань передбачають створення науково обгрунтованого, високопродуктивного сільськогосподарського землекористування з визначенням придатності земель для ведення розширеного виробництва. 
Таблиця 1

Еколого-економічна класифікація орних земель Тернопільської області

\begin{tabular}{|c|c|c|c|c|}
\hline \multirow[t]{2}{*}{ Клас } & \multicolumn{2}{|c|}{$\begin{array}{c}\text { Площа } \\
\text { Сільськогосподарських угідь }\end{array}$} & \multicolumn{2}{|c|}{$\begin{array}{c}\text { Оцінка грунтів за рівнем } \\
\text { окупності затрат }\end{array}$} \\
\hline & га & $\%$ & зернових & цукр. буряків \\
\hline 1 & 2 & 3 & 4 & 5 \\
\hline \multicolumn{5}{|c|}{ Природно-сільськогосподарський район (01) - 25 балів } \\
\hline 1 & 5435 & 26,7 & 1,93 & 2013 \\
\hline 2 & 2990 & 14,7 & 1,60 & 1,65 \\
\hline 3 & 2851 & 14,0 & 1,51 & 1,03 \\
\hline 4 & 8971 & 44,1 & 1,44 & 0,72 \\
\hline 1 & 2 & 3 & 4 & 5 \\
\hline 5 & 98 & 0,5 & 0,73 & 0,47 \\
\hline всього & 20345 & 100,0 & 1,60 & 1,28 \\
\hline \multicolumn{5}{|c|}{ Природно-сільськогосподарський район (02) - 35 балів } \\
\hline 1 & 28283 & 34,7 & 2,23 & 2,09 \\
\hline 2 & 24073 & 29,5 & 1,82 & 1,87 \\
\hline 3 & 12877 & 15,8 & 1,35 & 1,10 \\
\hline 1 & 2 & 3 & 4 & 5 \\
\hline 4 & 12697 & 15,6 & 1,26 & 0,88 \\
\hline 5 & 3592 & 4,4 & 0,96 & 0,69 \\
\hline всього & 81522 & 100,0 & 1,76 & 1,62 \\
\hline \multicolumn{5}{|c|}{ Природно-сільськогосподарський район (03) - 44 балів } \\
\hline 1 & 156369 & 64,2 & 2,09 & 1,83 \\
\hline 2 & 56901 & 23,4 & 1,91 & 1,58 \\
\hline 3 & 9465 & 3,9 & 1,06 & 0,96 \\
\hline 4 & 16939 & 7,0 & 1,42 & 1,99 \\
\hline 5 & 3720 & 1,5 & 1,04 & 0,55 \\
\hline всього & 243394 & 100,0 & 1,95 & 1,66 \\
\hline \multicolumn{5}{|c|}{ Природно-сільськогосподарський район (04) } \\
\hline 1 & 1040085 & 49,3 & 2,56 & 2,19 \\
\hline 2 & 52925 & 25,1 & 2,26 & 1,94 \\
\hline 3 & 4231 & 2,0 & 1,28 & 0,92 \\
\hline 4 & 44016 & 20,9 & 1,81 & 1,22 \\
\hline 5 & 5667 & 2,7 & 1,36 & 0,95 \\
\hline всього & 210924 & 100,0 & 2,27 & 1,87 \\
\hline \multicolumn{5}{|c|}{ Природно-сільськогосподарський район $(05)$ - 26 балів } \\
\hline 1 & 17419 & 29,7 & 2,09 & 1,85 \\
\hline 2 & 8028 & 13,7 & 1,79 & 1,63 \\
\hline
\end{tabular}


Продовж. табл. 1.

\begin{tabular}{|c|c|c|c|c|}
\hline 1 & 2 & 3 & 4 & 5 \\
\hline 1 & 2 & 3 & 4 & 5 \\
\hline 3 & 19881 & 33,9 & 1,12 & 0,94 \\
\hline 4 & 9021 & 15,4 & 1,13 & 0,77 \\
\hline 5 & 4323 & 7,4 & 0,89 & 0,64 \\
\hline всього & 58672 & 100,0 & 1,49 & 1,25 \\
\hline \multicolumn{5}{|c|}{ Природно-сільськогосподарський район (06)-25 балів } \\
\hline 1 & 49167 & 49,2 & 20,5 & 2,37 \\
\hline 2 & 41704 & 41,7 & 1,85 & 1,83 \\
\hline 3 & 4584 & 4,6 & 1,45 & 1,04 \\
\hline 4 & 3791 & 3,8 & 1,51 & 1,31 \\
\hline 5 & 782 & 0,8 & 0,91 & 0,94 \\
\hline всього & 100028 & 100,0 & 1,91 & 2,03 \\
\hline \multicolumn{5}{|c|}{ Природно-сільськогосподарський район (06)-25 балів } \\
\hline 1 & 22756 & 42,3 & 1,81 & 1,90 \\
\hline 1 & 2 & 3 & 4 & 5 \\
\hline 2 & 11608 & 21,6 & 1,59 & 1,65 \\
\hline 3 & 15073 & 28,0 & 1,21 & 0,92 \\
\hline 4 & 3512 & 6,5 & 1,05 & 0,91 \\
\hline 5 & 851 & 1,6 & 0,66 & 0,76 \\
\hline всього & 53800 & 100,0 & 1,53 & 1,49 \\
\hline
\end{tabular}

Така класифікація земель по областях дасть достовірну інформацію щодо оцінки грунтів за рівнем окупності затрат, а відтак і їх використання під вирощування конкретної сільськогосподарської культури.

Важливим напрямом інституційного забезпечення охорони земель області залишається боротьба з водною ерозією грунтів. Це стосується інституційного забезпечення грунтозахисної системи землеробства з контурно-меліоративною організацією території, що передбачає вилучення 3 інтенсивного обігу деградованих земель, ерозійно небезпечних земельних ділянок із подальшим залуженням схилів крутизною $3-7^{0}$, заліснення крутосхилів, будівництво протиерозійних гідротехнічних споруд, упровадження низки агротехнічних заходів, передбачених Національною програмою охорони земель. 
Через високу господарську освоєність земельного фонду з очевидно недостатніми обсягами заходів щодо охорони земель i ïx відтворення відбувається прогресуюча деградація грунтів, що створює загрозу екологічній безпеці області. Продуктивні землі продовжують деградувати внаслідок водної ерозії, підкислення, заболочення і перезволоження. Водній ерозії підлягає близько 40 \% сільськогосподарських угідь, і площа їх зростає стрімкими темпами за останні 40 років. Для покращення ситуації пропонується здійснити консервацію малопродуктивних і деградованих земель.

Суттєвою перешкодою для ефективного використання земель $\epsilon$ гідрологічний режим території, який спричиняє перезволоження і заболочення значного масиву угідь. Глибоке осушення грунтів спричиняє порушення водного балансу, режиму грунтових і підземних вод, що призводить до обводнення i появи нових ділянок заболочених земель. Для нормалізації водного балансу необхідно зменшити глибину дренування грунтів, залужувати такі землі вологолюбними травами та використовувати їх як поліпшені сіножаті. Тому скорочення площ осушених орних земель і виникнення повторно заболочених ділянок $\epsilon$ закономірним процесом. Такі ділянки необхідно залишити в нинішньому стані. Вони повинні формувати екологічний каркас території.

Інтенсивна втрата гумусу з грунтових горизонтів через ерозійні процеси та систематичне недодавання мінеральних і органічних добрив призводить до постійного спаду його вмісту в грунті сільськогосподарського призначення.

На сьогодні достатньо розроблена методика захисту грунтів від ерозії, економічного захисту цінних земель від необгрунтованого вилучення для несільськогосподарських потреб.

Впровадження інституційного забезпечення охорони земель допоможе забезпечити складання проектів, де, поряд із питаннями організації територій, вирішуються питання організаційно-господарського, агротехнічного, лісомеліоративного і гідротехнічного спрямування для ефективнішого використання земель, зростання культури землеробства та охорони земель на об’єднаних територіальних громад. 
Основним напрямом охорони земель області залишається:

- боротьба з водною ерозією грунтів;

- грунтозахисної системи землеробства 3 контурно-меліоративною організацією території;

- вилучення 3 інтенсивного обробітку деградованих земель, ерозійно небезпечних ділянок із подальшим залуженням схилів крутизною 3-7;

- залісненням крутосхилів;

- будівництвом протиерозійних гідротехнічних споруд, упровадження низки агротехнічних заходів.

- рекультивації проблемних територій, тобто комплексу організаційних, технічних і біотехнологічних заходів, спрямованих на відновлення грунтового покриву, поліпшення стану та зростання продуктивності порушених земель.

Водночас, у аграрному секторі економіки країни істотний вплив на використання земельних ресурсів мають внутрішньогосподарські причини, однією з яких є проблема недотримання науково обгрунтованого чергування культур у сівозмінах. Адже поява i розвиток невеликих за розміром сільськогосподарських підприємств сприяє поглибленню спеціалізації сільськогосподарського виробництва, що неминуче призводить до обмеження набору вирощуваних культур.

Приватизація земель громадянами також досі здійснюється без належного екологічного обгрунтування, дотримання вимог екобезпеки. Немає чітко встановленого механізму тимчасового або постійного вилучення 3 активного обігу земельних ділянок із природоохоронних міркувань (необхідність консервації, реабілітації, відведення під заліснення). Для ефективного вирішення цих актуальних питань необхідно було б керуватися комплексом обов'язкових заходів, щоб покласти край екстенсивному та екологічно необгрунтованому використанню земельних ресурсів у державі взагалі й у сільському господарстві зокрема. Було б реальним передати еродовані землі в приватну власність громадянину, який був би зацікавлений у їх збереженні. При цьому має 
спрацювати стимулюючий механізм: податкові канікули, зменшення земельного податку, за потреби - надання допомоги для виконання рекультивації земель.

Вагомий вплив в системі інституційного забезпечення хорони i використання земель сільськогосподарського призначення $\epsilon$ вливання інвестицій. Інвестиції розглядають як вкладення в капітал, як грошовий, так i реальний. Вони здійснюються у вигляді грошових коштів, банківських внесків, паїв, акцій та інших цінних паперів, внесків у рухоме та нерухоме майно, інтелектуальну власність, майнові права та інші цінності [34].

Розвиток будь-якої держави пов'язаний із динамікою інвестиційних процесів, структурним та якісним оновленням виробництва й створенням ринкової інфраструктури. Чим інтенсивніше здійснюється інвестування, тим швидше відбувається відтворювальний процес, i активніше - ефективні ринкові перетворення.

Інвестиції потрібні підприємствам i організаціям для переходу до нормальної господарської діяльності, для переозброєння виробництва, зростання якості продукції [35, с. 6].

Капітал і земля разом утворюють речове багатство України. I сьогодні, в умовах пошуку ефективної моделі функціонування пореформеного сільського господарства, не виникає суперечностей в надзвичайно важливій та стратегічній ролі інвестицій. Тому в період обмеженості інвестиційних ресурсів інвестиційна привабливість як категорія є основним критерієм, на основі якого формуються інвестиційна стратегія з боку інвестора та інвестиційна політика держави. Тому особливо актуальне питання визначення інвестиційної привабливості сільськогосподарського землекористування, як одного з перспективних напрямів залучення капіталу [36].

У здійсненні процесу інвестування сільського господарства має ряд особливостей, які випливають 3 умов та характеру сільськогосподарського виробництва. 
Основною відмінністю сільського господарства від інших галузей народного господарства $€$ не три а чотири виробничі ресурси - земля, основні і оборотні фонди, жива праця. Характерною ознакою $є$ те, що земля виступає і як знаряддя, і як предмет праці і є основним і незамінним засобом виробництва, на відміну від промисловості, де земля служить тільки просторовим базисом. Незамінним iї показником $\epsilon$ те, що при правильному використання земля не зношується, а навпаки, покращує свої якості.

Тому особливої актуальності набуває проблема інвестування природоохоронних заходів та впровадження нових технологій обробітку, вибір та складання заходів щодо реалізації інвестицій.

Ринкові зміни в економіці України вимагають чіткого визначення та дієвого управління поняттями й категоріями, стосовно інвестиційних відносин. Питання власності на землю $є$ важливим моментом довгострокових та великих інвестицій - саме тих інвестицій, які терміново необхідні потрібних Україні для розвитку іiї сільськогосподарського та промислового потенціалу [35].

Регіональний розвиток України відбувається досить складно і суперечливо конституція України визначила головний вектор перерозподілу економічних прав і повноважень на користь регіонів.

Зміна соціально-економічних умов господарювання визначає нові підходи до оцінки інвестиційного потенціалу регіонів. Це потребує аналізу, моніторингу та розробки шляхів вирішення проблем, пов'язаних з інвестиційною діяльністю на всіх регіональних рівнях. Формування ринкового інфраструктурного середовища передбачає створення диверсифікованої системи інвесторів, яка складається з агентів різних функціональних і соціально-економічних структур - виробничих, посередницьких, біржових, суто інвестиційних та інших підприємств.

У регіонах України ще не сформувалася мережа приватних інституційних інвесторів. Найбільшими потенційними приватними інституційними інвесторами є комерційні банки, які здійснюють переважно короткострокове 
кредитування найприбутковіших торгово-посередницьких операцій, а не інвестування.

Економіка країни, де вітчизняний інвестор практично не вкладає кошти у розвиток виробництва, не може бути привабливою для іноземного інвестора. Залучення іноземних інвестицій має здійснюватися 3 урахуванням цілей i завдань державних програм структурної переорієнтації виробництва, цільових програм міжгалузевого та галузевого розвитку, конверсії та розвитку експортного потенціалу. Слід брати до уваги також процеси внутрішньої й зовнішньої кооперації продукції виробничо-технічного призначення, приватизації державних підприємств із залученням іноземного капіталу.

Україна має змогу змінити свої позиції як покупець інвестицій за рахунок їх диверсифікації, отримуючи іноземні інвестиції у вигляді технологічного обладнання, матеріалів, прав інтелектуальної власності, ноу-хау, торгових знаків, деяких інших цінностей. Доцільність такого підходу підтверджена не тільки деякими зарубіжними фахівцями, а й досвідом окремих країн, наприклад, Японії, де закупівля та використання зарубіжних ліцензій значною мірою сприяли ії соціально-економічному розвитку.

У Державній цільовій програмі розвитку українського села визначені основні стратегічні напрями інноваційного розвитку аграрного сектора. Зокрема, впровадження сучасних технологій для вирощування i переробки сільськогосподарської продукції, розвитку селекції, меліорації та суттєвого поліпшення земель, а також створення умов для міжнародного співробітництва у сфері наукової та інноваційної діяльності.

Інвестиції необхідні сільському господарству, підприємствам, організаціям, особливо в нинішніх умовах реформування й переходу до ринкових відносин, для переходу до нормальної господарської діяльності, для переозброєння виробництва, зростання якості продукції. Для їхнього успішного функціонування держава повинна регулювати створення в країні сприятливого клімату, формування i розвиток фондового ринку, сприяти спрямуванню інвестицій у пріоритеті виробництва [37]. 
Для покращення становища сільськогосподарського землекористування доцільно запровадити заходи для розвитку інвестицій:

- інвестування здійснювати за власний рахунок (прибутків, амортизаційних відрахувань, відшкодування збитків землевласникам i землекористувачам при відчуженні земель);

за рахунок грошових нагромаджень і заощаджень власників землі тощо;

- позикових - банківських та бюджетних кредитів;

- залучення фінансових ресурсів інвестора (кошти, одержані від продажу акцій, пайові та інші внески громадян і юридичних осіб), а також бюджетних інвестиційних асигнувань та благодійних внесків, пожертв організацій, підприємств і громадян.

Формування інвестиційної привабливості сільськогосподарського землекористування та організації інвестиційного процесу в Україні тільки починають розвиватися. Тому одним із найактуальніших завдань сьогодення у сфері землекористування є дослідження та вдосконалення методологічних основ інвестиційної діяльності 3 метою зростання ефективності використання та охорони земель сільськогосподарських підприємств формуванням інвестиційної привабливості землекористування та удосконалення цього процесу через проекти землеустрою.

Сільськогосподарські підприємства як суб'єкти господарювання перебувають у сфері інвестиційної діяльності, де здійснюється практична реалізація інвестицій у їх землекористування. Вона охоплює сферу земельних відносин, землекористування, капітального будівництва, де реалізується вкладення інвестицій у майно, що належить до основного їі обігового капіталів, а також інноваційну сферу, де реалізуються науково-технічна продукція та інтелектуальні цінності, у сферу обігу фінансового капіталу (кошти, цінні папери й цільові грошові внески) та сферу реалізації майнових прав суб'єктів інвестиційної діяльності. 
Водночас, інвестування землекористування сільськогосподарських підприємств має певні характерні особливості. Зокрема, тут інвестиціями можуть бути інновації з організації сільськогосподарського землекористування, а інвесторами - як члени сільськогосподарських підприємств, так і зовнішні особи (організації) [38].

Враховуючи це структуру інвестиційного процесу у землекористування сільськогосподарських підприємств можна розглядати у такій послідовності виконання:

1) планування заходів (вибір інвестицій, розробка інвестицій, складання планів, програм, проектів);

2) місце прикладення інвестицій (земельні ділянки, матеріальні цінності, грошові кошти - банківські кредити тощо, трудова діяльність учасників та працівників;

3) реалізація інвестицій (організація землекористувань сільськогосподарських підприємств різного типу, поновлення матеріальнотехнічної бази господарств, грошові внески щодо поліпшення земель, будівництво нових та залучення старих інвестицій у господарства, розробка інших проектів).

Невід'ємною складовою, яка обов'язково повинна включатися в інвестиційну діяльність, є вартість земельних ділянок чи прав на них.

Оскільки засновниками сільськогосподарських підприємств можуть бути лише громадяни України, то й інвестиційна діяльність сільськогосподарських підприємств здійснюється за рахунок внутрішніх інвестицій і основними джерелами інвестицій сільськогосподарських підприємств $є$ прибуток та залучені кошти.

Слід ураховувати, що у сільськогосподарських виробничих кооперативах обмежені можливості залучення інвестиційних ресурсів випуском цінних паперів, тому вони переважно тільки реальні. Крім того, учасники кооперативу зацікавлені у використанні частини прибутку для спо-живання, тому його 
(прибутку) роль у розширенні інвестиційної діяльності сільськогосподарських виробничих кооперативів спадає. Обмеженість джерел інвестування зумовлює певну специфіку напрямів використання інвестицій залежно від інтересів засновників.

На нинішньому етапі розвитку економіки в загалом і для аграрного сектора зокрема, науково-інвестиційне забезпечення $\epsilon$ найважливішою складовою збільшення конкурентоздатності сільськогосподарської п продукції та продовольчих товарів як на внутрішньому, так і на зовнішніх ринках.

На сьогодні необхідно вирішити низку складних проблем, серед яких провідними $є$ стабілізація аграрного виробництва, істотне поліпшення фінансового стану сільськогосподарських підприємств різних форм власності, посилення інтенсивної діяльності в усіх сферах національного АПК.

Інвестиції можуть бути реальними лише тоді, коли держава створить усі умови найширшого розвитку приватного сектора сільського господарства та економіки загалом.

Інвестиційний процес охоплює:

- створення реального власника;

- залучення інвестицій;

- одержання засобів для поповнення державного бюджету, а також супровід процесу приватизації.

Слід відзначити, що важливу роль у формуванні сприятливого економічного середовища для активізації науково-інвестиційного забезпечення $\epsilon$ передусім ринкові реформи, які відбуваються в аграрному секторі поетапно. Урядова політика щодо вдосконалення й щорічного розширення обсягів державної підтримки розвитку аграрного сектора поступово формує таке сприятливе економічне середовище. Важливим також $є$ спад податкового навантаження на сільськогосподарські виробники.

Для розвитку інвестицій в аграрному секторі пропонуємо удосконалити систему заходів через: 
- розвиток системи іпотечного кредитування, зокрема іпотеки земельних ділянок;

- комплексне законодавче забезпечення впровадження ринку земель сільськогосподарського призначення;

- створення сучасної системи реєстрації нерухомості, зокрема земельних ділянок;

- розширення бюджетного фінансування фундаментальних наукових досліджень;

- розвиток системи страхування аграрних ризиків;

- забезпечення стабільної податкової політики та системи державної підтримки сільгоспвиробників;

- посилення гарантій захисту інвестицій та доходів інвесторів, забезпечення вільного руху капіталу та переміщення товарів.

Виконання цих заходів дасть змогу значно збільшити інвестиційну привабливість АПК, продовольчу безпеку держави та експортний потенціал галузі.

Інноваційно-інвестиційним заходам має належати довгострокове кредитування на підприємствах - інноваційно-інвестиційного фонду.

Аграрний сектор є одним із найпривабливіших для іноземних інвесторів, насамперед, можливостями росту, не обмеженими будь-яким втручаннями 3 боку держави” [39, с. 18], тим більше, що “...у Західній Свропі утворились значні доларові накопичення, які можуть бути використані й як інвестиції ”.

Важливим недоліком, який впливає на інвестування агропромислового комплексу України, є несприятливі ринкові умови виробництва: незначна прибутковість і високий ризик неповернення внесків, недосконале інвестиційне законодавство [40, с. 116]. Також до недоліків слід зарахувати відсутність податкових пільг для іноземних інвесторів, ефективної системи страхування інвестиційних ризиків, низький рівень розвитку інфраструктури села, доступ де банків, кредитних спілок у сільській місцевості. Гострою проблемою аграрних товаровиробників є відсутність шляхів збуту виробленої продукції (74% 
обстежених підприємств) і високі відсоткові ставки (близько 53 \%). Це дуже важливо для інвесторів, які мають можливості й доступ на зовнішні ринки щодо Сільськогосподарський i земельний фонд України характерний наявністю високого біопродуктивного потенціалу, в його структурі переважають землі 3 родючими грунтами. За експертними оцінками, за раціональної структури землекористування і відповідного наукового й ресурсного забезпечення, українські землі здатні виробляти продуктів харчування на 140-135 млн осіб.

Для створення привабливих земельних ресурсів необхідно вдосконалити систему рентних платежів.

Сутність схеми рентних платежів полягає у диференціації закупівельних цін на продукцію, виходячи зі середніх затрат виробництва у відповідній зоні. При цьому для зон із відносно гіршими умовами сільськогосподарського виробництва в землекористуванні встановлювався вищий рівень закупівельних цін. Отже, регулюючи закупівельні ціни на сільськогосподарську продукцію, державні органи вилучали більшу частину вартості продукції сільського господарства. Проте держава повертала частину вилученого в різних формах (постачала технікою, добривами, коштами). Цій формі економічної взаємодії держави і сільського господарства відповідала форма організації виробництваколгоспи, радгоспи.

За переходу до ринку змінюються методи регулювання економіки, де основою економічного управління стає державний бюджет, головним джерелом наповнення є податки. Отже, є потреба у відновленні науково обгрунтованих методів визначення ставок земельного податку.

До цього методу належить метод макроренти, через “... забезпечення реальних стартових економічних умов відтворення для всіх товаровиробників, стимулювання їх ефективнішого господарювання" [41, с. 43-44], застосування якого відновлює порушене плановою економікою істинне співвідношення між земельною рентою та ії формами - нормативною ціною землі, земельним податком, орендною платою. 
Земельний податок набуває значення як механізм забезпечення раціонального використання та охорони земель сільськогосподарського призначення, відтворення їх продуктивності, споживчих якостей та екологічної ролі грунтового покриву.

На сьогодні земельний податок розглядають як ставку, яка грунтується на нормативному розмірі земельної ренти, тобто є нормативом. Рента залежить від місця розташування земельних ділянок, ефективності додаткових вкладень у землю. Земельний податок $є$ механізмом розподілу земельної ренти, де необхідно враховувати умови:

- диференціальна рента є основною частиною земельної ренти, яка складається з ренти I і II. Джерелом диференціальної ренти I є вища родючість земельних ділянок i вигідніше їх місцерозташування щодо ринків збуту, порівняно з кращими ділянками, диференціальна рента II - ефективніша віддача витрат виробництва на земельних ділянках;

- принцип визначення й кількісні параметри податкових ставок будуть різними, залежно від форми власності на землю.

Держава економічно стимулюватиме охорону через правові та економічні механізми, які грунтується на удосконаленні механізму раціонального використання коштів від плати за землю.

В системі інституційного забезпечення раціонального використання i охорони земельних ресурсів важливою складовою $є$ вдосконалення інституційного механізму через формування ландшафтно-екологічних комплексів та земельних масивів угідь і сівозмін. Розглянемо детальніше.

Світовий досвід вказує на те, що у країнах з вільною ринковою економікою структура інститутів земельної власності збігається із загально цивілізованою структурою власності. Вона передбачає поділ їх на два основних інститути: публічну власність і приватну, яка в Україні конституційно закріплена. Публічна, тобто державна і комунальна власність, і приватна, охоплює власність фізичних та юридичних осіб 
Із інституційного погляду, землі - сукупність кадастрових, майнових та інших спеціальних закладів, а також структур органів юстиції, завдяки яким, відповідно до правил, чинних законів відбувається перерозподіл землі між учасниками земельних відносин. До цих закладів і структур належать: державні земельні служби, проектні інститути, бюро технічної інвентаризації, суди, різні страхові й кредитні установи.

Ринок землі - інституційна система, через яку здійснюються всі види діяльності, які пов'язані з передачею прав на земельні ділянки [42].

Сучасна інституційна структура класифікується за основними показниками:

- правовим - удосконалення і прийняття земельного законодавства (реєстрація прав власності одночасно на земельні ділянки і розташовані на них об'єкти нерухомості, забезпечення правових умов обороту земель сільськогосподарського призначення, у тому числі іпотека; здійснення різних цивільно-правових робіт із земельними ділянками і тощо );

- територіальним - завершення зонування територій і розмежування земель державної та комунальної власності;

- функціональним - продаж земельних ділянок, придбання земельних ділянок із відтермінуванням платежу тощо;

- процедурним - удосконалення механізму передачі права власності на земельні ділянки, які перебувають у державній або комунальній власності, спрощення процедурних прав на земельні ділянки в цілях реалізації інвестиційних процесів, удосконалення системи реєстрації прав на земельні ділянки тощо;

- природоохоронним - організація ефективного контролю за охороною й використанням земельних ресурсів, спрямованих на збереження й відновлення природних якостей земель.

Проблема інституційного забезпечення державної земельної політики на регіональному й місцевому рівнях пов'язана 3 незавершеністю формування 
сільськогосподарських підприємств на основі приватної форми власності. Місцеві органи влади не мають належного законодавчого забезпечення та фінансової бази для вирішення таких проблем. Розбудова системи державного управління земельними ресурсами є багатоаспектним комплексним завданням, яка потребує окремого розгляду й вироблення відповідної системи заходів.

Для ефективної реалізації державної земельної політики необхідно створити мережу недержавних інституцій регіонального і місцевого розвитку. Такі інституції покликані підвищити роль і відповідальність територіальних громад, землевласників і землекористувачів за розвиток відповідних територій, забезпечити їм можливість реальної участі та впливу на вирішення важливих проблем регіонального і місцевого розвитку. Також інституцією може бути мережа агентств регіонального розвитку 3 репрезентуванням державних, громадських, приватних інтересів.

Удосконалення правового регулювання земельних відносин є основною умовою для спрямування дій місцевих органів виконавчої влади та органів місцевого самоврядування на створення й підтримку сприятливого середовища для розвитку землеволодінь і землекористувань. Однак для цього необхідно впровадити дієві механізми взаємодії влади із власниками наділів (паїв) на підставі соціального партнерства, розробляти й реалізовувати регіональні та місцеві програми розвитку нових форм господарювання.

Регіональні програми повинні спрямовуватися на комплексне вирішення питань розвитку та підтримки нових форм господарювання на землях приватної форми власності, в межах повноважень місцевих органів влади, а саме: вдосконалення нормативно-правової бази; зменшення податкового тиску; впровадження системи фінансово-кредитної та ресурсної підтримки селянських господарств; сприяння розвитку інфраструктури підтримки господарств нового типу.

У більшості районів площі необроблюваних земель щороку зменшуються, а в окремих - усі продуктивні землі вже нині перебувають в обробітку. Отже, їх 
передусім слід упорядкувати 3 урахуванням змін, причин, чинників за багаторічний період, які тією чи іншою мірою вплинули на погіршення ситуації. Одним iз головних способів їх наукового 3’ясування $є$ складання схем землеустрою й охорони земель, які є основою для планування, впровадження заходів із раціонального використання земельних ресурсів, їх збереження та відтворення. Виконання цих робіт передбачається за кошти, які надходять у порядку відшкодування втрат сільськогосподарського та лісогосподарського виробництва. Водночас можна вирішувати питання використання і відтворення природних ресурсів, збереження цілісності природних комплексів (об'єктів природно-заповідного комплексу та природоохоронного призначення) та об’єктів історико-культурного призначення.

Для раціонального використання земельних ресурсів слід звернути увагу на ландшафтно-екологічні пріоритети території області. Поділ території області на ландшафтно-екологічні комплекси визначає напрямок розвитку області, специфіку їі господарської діяльності в масштабах країни та в природних територіальних комплексах, що сприяє розвитку антропогенних і екологічних функцій iз створенням комфортних i стабільних умов середовища для життєдіяльності людей та природоохоронні функції зі збереженням природних ландшафтів.

Для визначення природоохоронної функції як пріоритетної для будь-якого регіону, при виділенні ландшафтно-екологічних комплексів території області основним завданням $€$ визначення оптимального співвідношення між природними і освоєними господарськими територіями.

У науковій літературі існують різні обгрунтування щодо співвідношення між природними й антропогенними ландшафтами в межах регіону. Наприклад, В.О. Молчанов мінімальну лісистість території лісостепової зони визначив в межах 20 \%, а O.I. Воєйков - 17-23 \%. При узагальнені цих даних можна прийняти за середнє значення показника лісистості орієнтовно у лісостеповій зоні області у 20 \%. Приблизно таку саму площу займатимуть лучно-степові, водно-болотні рослинні утворення. Отже, близько 40 \% площі будь-якого 
регіону повинні бути зайняті під природною рослинністю, для забезпечення природної стабільності. Розглянемо детальніше формування ландшафтноекологічних комплексів за співвідношення між природними та антропогенними ландшафтами на прикладі тернопільської області.

У межах Тернопільської області під природною рослинністю перебуває близько 30 \% площ, що свідчить про нестабільність ландшафтно-екологічної структури території.

Проведемо розподіл земель області щодо їх співвідношення між природними та антропогенними ландшафтами з метою поетапного виводу цих земель із сільськогосподарського обробітку, 3 подальшим використанням масивів екологічної придатності земель на ріллі, та їх раціональному використанню. Вирішення цих завдань дозволить мата кращу картину щодо якості земель, можливостей їх використання, та інвестиційної привабливості.

Узагальнивши показники природних та антропогенних ландшафтів у районах Тернопільської області здійснено групування за процентним співвідношенням, результати яких показано в таблиці 2 . та рис. 1.

Таблиця 2

Утворення ландшафтно-екологічних комплексів за співвідношення між природними та антропогенними ландшафтами у районах в області.

\begin{tabular}{|c|l|c|c|c|}
\hline \multirow{2}{*}{$\begin{array}{c}\text { № } \\
\text { 3/п }\end{array}$} & \multirow{2}{*}{$\begin{array}{c}\text { Адміністративні } \\
\text { утворення }\end{array}$} & $\begin{array}{c}\text { Загальна } \\
\text { площа } \\
\text { земель, га }\end{array}$ & $\begin{array}{c}\text { Частка природних та } \\
\text { антропогенних ландшафтів, \% }\end{array}$ \\
\hline \multicolumn{5}{|c|}{ Найкраще співвідношення } \\
\hline 1 & 2 & 3 & 4 & 5 \\
\hline 1 & Бережанський & 66113,0 & 54,6 & 45,4 \\
\hline 2 & Шумський & 83800,0 & 43,6 & 56,4 \\
\hline 3 & Монастирський & 55815,0 & 47,2 & 52,8 \\
\hline \multicolumn{5}{|c|}{ Гірше співвідношення обласного (30\%-70\%) } \\
\hline 4 & Бучацький & 80212,0 & 33,1 & 66,9 \\
\hline 5 & Заліщицький & 68391,0 & 31,9 & 68,1 \\
\hline 6 & Зборівський & 97740,4 & 32,3 & 67,7 \\
\hline 7 & Кременецький & 91754,0 & 37,8 & 62,2 \\
\hline
\end{tabular}


Продовж. табл. 2

\begin{tabular}{|c|l|c|c|c|}
\hline 1 & 2 & 3 & 4 & 5 \\
\hline 8 & Борщівський & 100587,0 & 30,9 & 69,1 \\
\hline 9 & Підгаєцький & 49638,0 & 34,9 & 65,1 \\
\hline \multicolumn{5}{|c|}{ Погане співвідношення (вище за 70\%) } \\
\hline 10 & Густинський & 101616,0 & 27,7 & 72,3 \\
\hline 11 & Збаразький & 86306,0 & 23,6 & 76,4 \\
\hline 12 & Козівський & 69430,0 & 25,0 & 75,0 \\
\hline 13 & Лановецький & 63234,0 & 21,6 & 78,4 \\
\hline 14 & Підволочиський & 83726,0 & 18,6 & 81,4 \\
\hline 15 & Теребовлянський & 113003,0 & 22,2 & 77,8 \\
\hline 16 & Тернопільський & 74911,0 & 25,1 & 74,9 \\
\hline 17 & Чортківський & 90344,0 & 24,6 & 75,4 \\
\hline
\end{tabular}

Згідно 3 даними табл. 2, найкраще співвідношення між природними й антропогенними ландшафтами характерне тільки для трьох адміністративних районів - Бережанського (54,6 \% порівняно з 45,4 \%), Монастирського (47,2 \% порівняно 3 52,8 \%), Шумського (43,6 порівняно 56,4%); у шести адміністративних районах співвідношення гірше за встановлене обласне (30\% порівняно 3 70,0 \%), а в решти восьми адміністративних районів співвідношення погане. При цьому встановлено, що господарська освоєність території області становить 70\% площ, з яких 61,8 \% є розораними.

Враховуючи цю обставину, а також значну частину малопродуктивних і сильноеродованих земель, доцільним провести виведення їх 3 інтенсивного обробітку і на цих площах здійснювати заліснення і залуження, оскільки ці землі, зазвичай, малопродуктивні й деградовані, потребують консервації і спеціального використання. Залісненню підлягають деградовані орні землі з крутизною схилу понад 5-70 (понад 14 тис. га). Ці землі знаходяться переважно з одного боку до схилів горбистої місцевості, а з іншого до схилів річкових долин. Ці землі як правило малопродуктивні i деградовані i потребують спеціального функціонального використання, в тому числі консервації. Такі землі $є$ в кожному адміністративному районі області. Під заліснення доцільно відвести деградовані 
орні землі з крутизною схилу понад $7^{0}$ а це становить 40,1 тис. га, порушені та відпрацьовані землі промислового використання 4,7 тис. га, та радіаційно забруднені землі (17,8 тис. га), що загалом становлять 3,8 \% території області. Залуженню та залісненню, залежно від конкретних місцевих умов, підлягають малопродуктивні сільськогосподарські землі з крутизною схилів $5-7^{0}$ у межах річкових долин, місцях витоку річок (53,5 тис. га), частина малопродуктивних i деградованих орних земель із крутизною схилів $3-5^{0} 176,2$ тис. га що становить 13\% від площі області.

Співвідношення між природними та антропогенними ландшафтами у районах області показано на рисунку 1 згідно табличних даних 3 , де в кольоровому зображенні проведено групування адміністративних районів згідно частки в них природних та антропогенних ландшафтів.

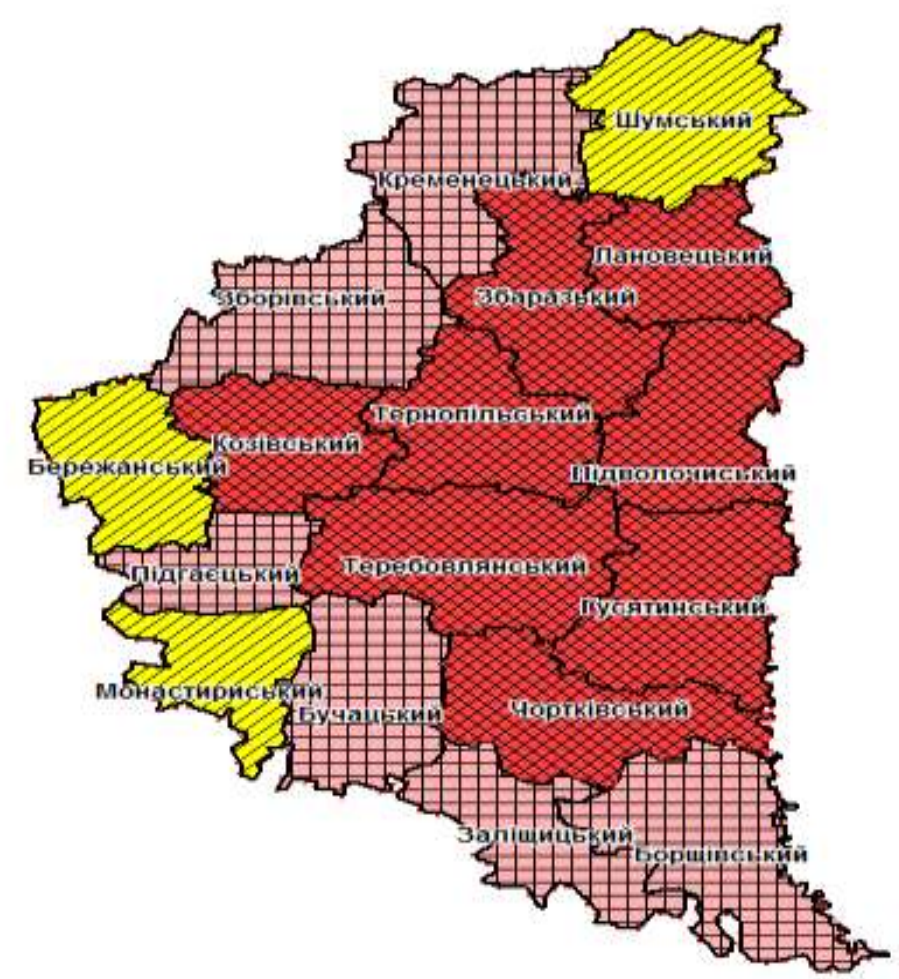

- найкраще співвідношення

\#\#- гірше співвідношення обласного (30\% - 70\%)

- погане співвідношення (більше за 70\%)

Рисунок 1. Співвідношення природних та антропогенних навантажень в районах області 
Згідно рисунку 1 нами відображено:

- в жовтих тонах - найкраще співвідношення між природними та антропогенними ландшафтами;

в рожевих тонах - гірше співвідношення між природними та антропогенними ландшафтами (30-70\%);

- $\quad$ в червоних - погане співвідношення (більше 70\%) між природними та антропогенними ландшафтами.

Провівши ці заходи (перший етап створення ландшафтно-екологічних комплексів) площа природної рослинності збільшиться до 50 \%.

Ha другому emani створення ландшафтно-екологічних комплексі пропонуємо надати статус перспективної екологічної мережі полезахисним лісосмугам, ділянкам витоку річок, водно-болотним масивам, землям під ярами, пісками, водою, а також луками, сіножатями, пасовищами, що в сукупності становитиме 439,0 тис. га (32,6 \%). Вилучення їх із господарського користування цілою площею неможливе. Це можна здійснити запровадивши поступову зміну режимів природокористування із залученням їх до складу буферних зон майбутніх коридорів. До них належать річкові долини Дністра, Золотої Липи, Стрипи, Серету, Збруча які становлять близько 158 тис. га (11,4 \%) земель річкових долин.

На основі звітних даних запропонована прогнозна структура земельних угідь регіональної екологічної мережі.

Таблиця 3.

Прогнозована структура земельних угідь в регіональній екологічній мережі області

\begin{tabular}{|c|c|c|c|}
\hline Угіддя & $\begin{array}{c}\text { Угіддя } \\
\text { тис. га }\end{array}$ & $\begin{array}{c}\text { Частка у } \\
\text { аг. площі } \\
2019 \text { р. \% }\end{array}$ & $\begin{array}{c}\text { Частка у аг. } \\
\text { площі на } \\
\text { перспективу } \\
\%\end{array}$ \\
\hline 1 & 2 & 3 & 4 \\
\hline Ліси та лісо вкриті площі, у т. ч. & 198,389 & 14,3 & 18,2 \\
\hline ліси & 132,258 & 9,6 & 12,6 \\
\hline лісосмуги & 60,998 & 4,4 & 4,8 \\
\hline
\end{tabular}


Продовж. табл. 3

\begin{tabular}{|c|c|c|c|}
\hline 1 & 2 & 3 & 4 \\
\hline Чагарники & 5,132 & 0,4 & 0,8 \\
\hline Сіножаті & 37,596 & 2,7 & 10,0 \\
\hline пасовища & 137,777 & 9,5 & 18,8 \\
\hline Заболочені землі & 4,970 & 0,3 & 0,5 \\
\hline $\begin{array}{c}\text { Землі з незначним рослинним } \\
\text { покривом, у т. ч. }\end{array}$ & 17,831 & 1,3 & 1,3 \\
\hline кам'янисті землі & 8,289 & 0,6 & 0,6 \\
\hline інші відкриті землі & 9,542 & 0,7 & 0,7 \\
\hline Землі під водою, у т. ч. & 19,381 & 1,4 & 1,4 \\
\hline природні водотоки & 5,935 & 0,4 & 0,4 \\
\hline штучні водотоки & 3,273 & 0,2 & 0,2 \\
\hline озера & 0,679 & 0,1 & 0,1 \\
\hline водосховища, ставки & 9,494 & 0,7 & 0,7 \\
\hline Всього & 409,946 & 29,6 & 50,2 \\
\hline
\end{tabular}

Tpemiŭ eman формування ландшафтно-екологічних комплексів повинен започаткувати роботу з функціонування цілісної екологічної мережі, коли до іiі складу будуть включені екологічні коридори, зони відновлення природної рослинності із певним режимом використання - антропоекологічноїим, агрогосподарським і рекреаційним.

Розвиток туристично-рекреаційного комплексу як пріоритетного господарського напряму сприяє залученню природних рекреаційних ресурсів до масового відпочинку й оздоровлення населення. Частка природної рослинності повинна невпинно зростати через відновлення регіональних та природних національних парків.

Серед областей країни, в Тернопільській області переважає сільськогосподарський напрямок ведення господарства. Тому дані оцінки земель на даний час для області $\epsilon$ важливими щодо іï ефективного ведення господарювання, залучення інвестицій як внутрішніх так іноземних на основі організації раціонального використання земель. 
Розглядав цю проблему і М.M. Третяк, який для більш організованого використання земель, особливо сільськогосподарського призначення, запропонував еколого-економічну оцінку придатності земель, за якою орні землі поділено на 3 групи та 5 класів придатності. В основі такого поділу покладено окупність затрат на вирощування сільськогосподарських культур в розмірі 1,35 i відповідна змитість земель.

Ми пропонуємо дещо іншу систему у вирішенні проблеми раціонального використання земель в новостворених господарствах, що дозволить зробити їх інвестиційно-привабливими - система формування земельних масивів угідь та сівозмін з врахуванням екологічної придатності земель.

В західних областях України і в тому числі в Тернопільській області, найбільш розповсюдженими культурами є: зернові, картопля, цукровий буряк та кормові культури. Враховуючи це, для вирішення питання ефективного використання орних земель допоможе формування земельних масивів в основі яких лежить екологічна придатності земель. Для цього необхідно застосувати матеріали обліку якості і оцінки земель виділяються найбільш родючі земельні ділянки, які характеризуються середньою і сильною ступенем змитості грунтів, а так же низькими показниками часткових оцінок по урожайності культур і окупності затрат. На таких землях, як правило, необхідно розміщувати культури суцільного посіву, які б носили грунтозахисний характер. Слабозмиті землі, якщо їх в господарствах багато, слід об’єднувати для раціонального використання.

В системі земле оціночних робіт, що входять в складову державного кадастру, важливе місце займають дані про оцінку землі в цілому і внутрігосподарської в тому числі в розрізі окремих земельних ділянок, масивів, угідь, які характеризують продуктивність, ефективність використання i дохідність з одиниці площі. Дані про внутрігосподарську оцінку землі відображують якісний склад грунтів які впродовж років змінюються і вплинули на такі економічні показники як окупність затрат (О3), урожайність (У), вартість валової продукції (ВВП), диференційний дохід (ДД). Це стримує науково- 
обгрунтоване вирішення багатьох питань планово-економічного регулювання виробництва в сільськогосподарських підприємствах які утворюються чи змінюються відповідно до правового статусу.

Для впровадження механізму формування земельних угідь та сівозмін основною вимогою $є$ вирішення питання екологічної придатності земель. Виділення екологічно придатних земель для вирощування сільськогосподарських культур проведено за показником окупності затрат, вихідний рівень якого по Україні встановлено в розмірі 1.6, часткових економічних оцінок, яка відображає величину урожайності відповідної культури та затрат на ії вирощування, що становить для зернових культур - 25, цукрового буряка - 39, картоплі - 27 та кормових -25 .

Застосовуючи встановлені показники окупності затрат, урожайності культур, бали часткової оцінки земель для кожного господарства, в умовах Лісостепової зони Західних областей України пропонується виділяти наступні земельні масиви:

1. масиви земель для вирощування всіх сільськогосподарських культур;

1. масиви земель придатні для вирощування зернових, цукрового буряка, картоплі;

2. масиви земель придатні для вирощування всіх сільськогосподарських культур, картоплі;

3. масиви земель придатних під посіви зернових культур;

4. землі обмеженої придатності земель під посів зернових культур.

При виділенні таких груп земель допускає переміщення посівів із однієї групи в іншу але в структурі посівних площ питома вага яких встановлюється диференційовано і має бути меншою ніж на землях попередніх груп.

Виходячи 3 цього, оптимальну вагу посівів культур у кожній групі в залежності від наявності площі екологічно придатних земель для їх вирощування можна визначити застосувавши формулу:

$$
\text { Voп }=\frac{V \times P n p}{P_{3 a 2}}
$$


Де Vоп - оптимальна питома вага посівів культур;

$\mathrm{V}$ - питома вага посівів культур, прийнята в цілому по господарству, \%

Рпр - виділена площа ріллі в масиві, екологічно придатна для вирощування даної культури, \%;

Рзаг - загальна посівна площа екологічно придатних по господарству земель для вирощування даної культури, \%.

Вирішивши питання формування земельних масивів необхідно звернути увагу на вдосконалення сівозмін та ефективність вирощування відповідних культур в цих масивах, яка залежить від розмірів матеріально-грошових затрат на один центнер продукції. Одержання однакової кількості продукції з одного гектара посівів на землях різної якості супроводжується різною величиною затрат. В зв'язку 3 цим, для створення інвестиційної привабливості сільськогосподарських підприємств які мають різні за якістю грунти, необхідно проаналізувати де доцільно вирощувати культуру - на земельних угіддях кращих в екологічному відношення землях, займаючи при цьому мінімально необхідну площу, чи на гірших грунтах , займаючи більшу площу.

Для оцінки варіантів розміщення посівів сільськогосподарських культур на грунтах різної якості рекомендується визначати і співставити розмір чистого доходу відповідної продукції з одиниці площі. Приріст чистого доходу буде характеризуватися ефективністю використання тої чи іншої продукції.

Розмір чистого доходу на вирощування одної і тої ж культури на землях різної якості не одинаків і визначається як різниця вартості валової продукції і затрат (ЧД = ВП - 3). Якщо виробник ставитиме завдання планування по виробництву і продажу конкретної продукції, то в структурі чистого доходу величина валової продукції потребує різної величини посівної площі на різних за якістю землях. яка співставляється у вигляді кадастрової (умовної) площі через бали оцінки землі. В цьому випадку посівна площа (P) на гірших землях повинна бути більшою, в залежності від різниці в балах оцінки земель. Відповідно, для одержання запланованої величини валової продукції на кращих землях необхідну посівну площу позначимо Рк, а на гірших - Рг, дорівнює: 


$$
\mathrm{P}_{\Gamma}=\text { РК } \mathrm{x} \text { БК / БГ }
$$

Враховуючи, чо чистий дохід становить ЧД $=$ ВП -3 , а валова в даному випадку на кращих і гірших землях повинна бути однаковою $(\mathrm{BПг}=$ ВПк), його величина на землях:

$$
\begin{aligned}
& \text { - кращої якості складе ЧДк = ВП - Зк } \\
& \text { - гіршої якості - ЧДг = ВП - Зг }
\end{aligned}
$$

Де ЧД - чистий дохід;

ВП - валова продукція;

Зк - затрати на кращих землях;

Зг - затрати на гірших землях;

Так, як затрати на гірших землях будуть більшими ніж на кращих на величину різниці площі гірших і кращих земель, то і величина чистого доходу зменшиться на цю величину $(\Delta 3)$, тобто, ЧДг = ВП - (Зл $+\Delta 3)$. Отже додатковий чистий дохід дорівнюватиме:

$$
\begin{gathered}
\Delta \text { ЧД = ЧДк - ЧДг }=\text { ВП - Зк }- \text { ВП }+(3 \kappa=\Delta 3)= \\
\text { ВП }-3 \kappa-\text { ВП }+3 \kappa+\Delta 3=\Delta 3
\end{gathered}
$$

Враховуючи те, що в основу формування сільськогосподарських підприємств покладена оренда земельних ділянок, кожна з яких має свій розмір відповідно до якості грунту, планування одержання продукції буде більш нагляднішим i реальним. Користувач-виробник зможе оцінити розміщення окремої культури на відповідних землях за їх якістю.

Отже, механізм формування ландшафтно-екологічних комплексів дасть можливість провести розподіл земель області між природними та антропогенними ландшафтами 3 метою поетапного виводу цих земель із сільськогосподарського обробітку, та запровадження масивів екологічної придатності земель на повноцінних сільськогосподарських угіддях, що забезпечить їх інституційне використання. 